\title{
Peltigera hydrophila (Lecanoromycetes, Ascomycota), a new semi-aquatic cyanolichen species from Chile
}

\author{
Jolanta Miadlikowska1*, Nicolas Magain ${ }^{1,2}$, William R. Buck ${ }^{3}$, Reinaldo Vargas Castillo4, \\ G. Thomas Barlow ${ }^{1}$, Carlos J. Pardo-De la Hoz ${ }^{1}$, Scott LaGreca ${ }^{1}$ \& François Lutzoni ${ }^{1}$
}

\author{
Article info \\ Received: 29 Jan. 2020 \\ Revision received: 23 Mar. 2020 \\ Accepted: 24 Mar. 2020 \\ Published: 2 Jun. 2020
}

\section{Associate Editor}

Damien Ertz

\begin{abstract}
Peltigera hydrophila, a new species from Chile tentatively distinguished based on phylogenetic evidence but not yet named, is formally described here. Morphological differences (e.g., non-tomentose thallus) and habitat preferences (semi-aquatic) corroborate molecular and phylogenetic distinctiveness of this early diverging lineage in section Peltigera. Due to overlapping ecological ranges, $P$. hydrophila shares some morphological traits with aquatic species from the phylogenetically unrelated section Hydrothyriae.
\end{abstract}

Key words: cyanolichen, cyanobiont, Nostoc, mycobiont, symbiosis, taxonomy

\section{Introduction}

The most recent multi-locus phylogenetic revision of sections Peltigera and Retifoveatae of the genus Peltigera (Fig. 1) suggested the presence of 88 species, of which 50 were new to science (Magain et al. 2018). Forty-nine of the newly delimited species are part of section Peltigera, which includes species with tomentose thalli (with some exceptions, e.g., P. frigida and P. degenii) and lacking secondary metabolites detectable by thin layer chromatography (Miadlikowska \& Lutzoni 2000; Magain et al. 2018). Most of these newly delimited putative species are restricted to a single biogeographic region, and hence few are widespread. In section Peltigera, specificity of Peltigera species (mycobionts) in their association with Nostoc phylogroups (cyanobionts) ranges from strict specialists (associating with only one Nostoc phylogroup) to broad generalists (up to eight Nostoc phylogroups), with widespread Peltigera species recruiting a broader selection of Nostoc phylogroups than species with limited distributions (Magain et al. 2018). One potentially new species, $P$. sp. 13, was found to belong to section Retifoveatae (Fig. 1B).

Two species - Peltigera sp. 14 and P. sp. 16 - were found to be part of the two earliest diverged lineages

\footnotetext{
${ }^{1}$ Department of Biology, Duke University, Box 90338, Durham, NC 27708, USA

2 Evolution and Conservation Biology, InBios Research Center, Institut de Botanique B22, Université de Liège, Chemin de la vallée 4, 4000 Liège, Belgium

${ }^{3}$ Institute of Systematic Botany, New York Botanical Garden, 2900 Southern Boulevard, Bronx, NY 10458-5126, USA

${ }^{4}$ Departamento de Biología, Universidad Metropolitana de Ciencias de la Educación, Avda. José Pedro Alessandri 774, Ñuñoa, Santiago, Chile

* Corresponding author e-mail: jolantam@duke.edu
}

(clades $2 \mathrm{a}$ and $2 \mathrm{~b}$, respectively) within section Peltigera (Fig. 1B). Both species seem to be morphologically distinct and geographically restricted, however multiple collections from different localities are available only for $P$. sp. 14. Together with its sister species $P$. aubertii, known from the Holantarctic Kingdom (Martínez et al. 2003), P. sp. 14, which is restricted to Chile, represents the first divergence event within section Peltigera (Fig. 1B). This species was recognized as potentially new to science by Miadlikowska et al. (2014; corresponding to 'Peltigera sp. nov.') in the phylogenetic context of the Lecanoromycetes. Peltigera sp. 14 is one of the rare cases in the genus Peltigera where both symbionts are specialists and associate almost exclusively with each other (Magain et al. 2017a, b, 2018; Miadlikowska et al. 2018; Pardo-De la Hoz et al. 2018; Chagnon et al. 2019). The mycobiont forms thalli with Nostoc phylogroup XXIII, which was also found in a single specimen of its closest relative, $P$. aubertii, a species also found in Chile that otherwise associates with phylogroup XXII (Magain et al. 2018). Peltigera sp. 14 is the second water-associated lineage in the genus Peltigera. However, this species has a broader ecological amplitude than the distantly related North American species of section Hydrothyriae (Fig. 1A), as it can also grow in moist terrestrial habitats (e.g., on mosses subjected to waterfall splashes) compared to the strictly aquatic $P$. aquatica, $P$. hydrothyria, and $P$. gowardii of section Hydrothyriae. Here, we formally describe $P$. hydrophila to accommodate Peltigera sp. 14, the non-tomentose, semi-aquatic new species in section Peltigera. 


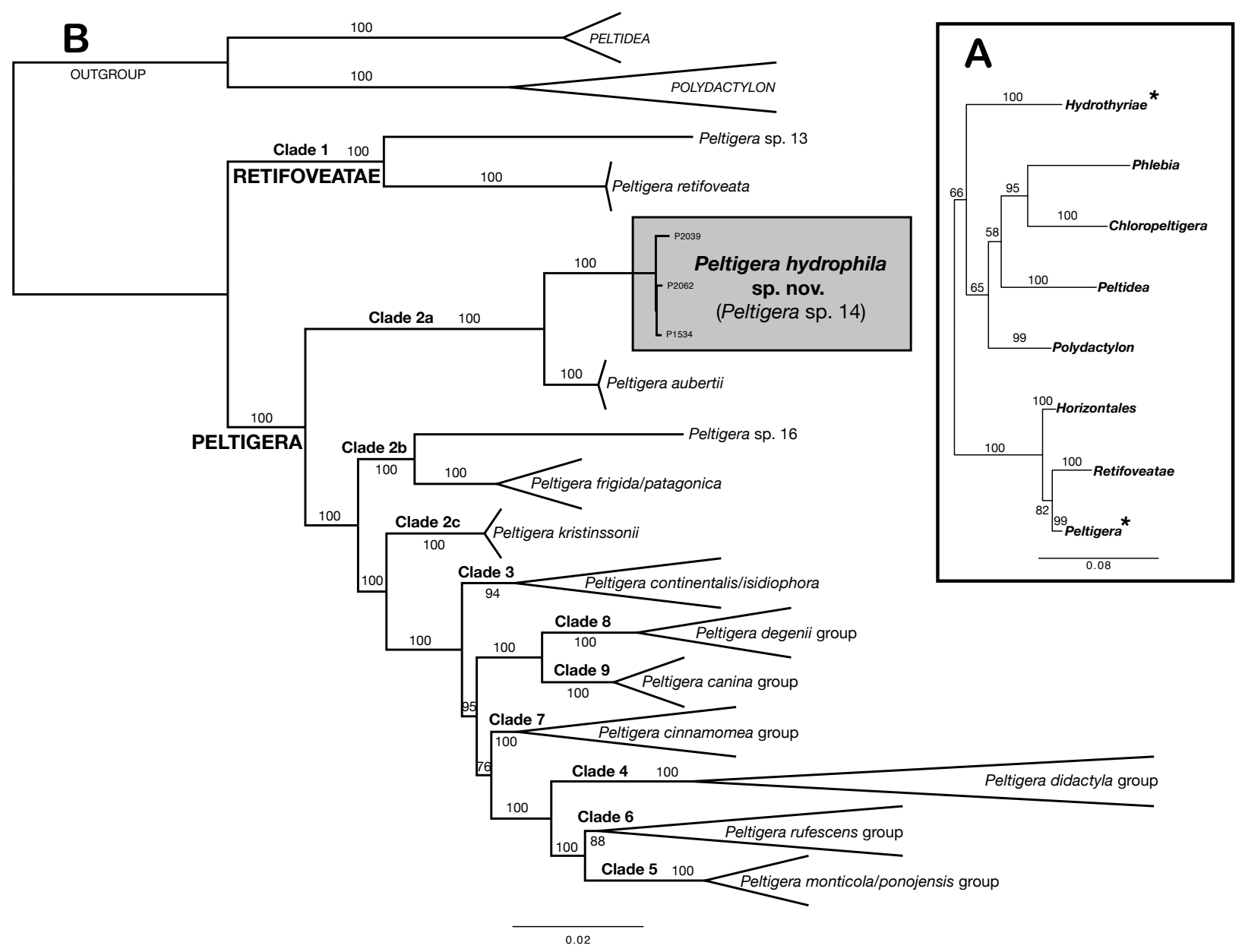

Figure 1. Phylogenetic placement of section Peltigera and the aquatic to semi-aquatic lineages (indicated by asterisks for section Hydrothyriae and P. hydrophila sp. nov. within section Peltigera) in the context of the genus Peltigera (A) and phylogenetic relationship of $P$. hydrophila sp. nov. within section Peltigera (B). Maximum Likelihood (ML) tree for the genus Peltigera (based on seven loci: ITS, nrLSU, $\beta$-tubulin, RPB1, COR1b, COR3, COR16; panel A) is adapted from Figure 2 of Chagnon et al. (2019). Intrageneric classification (i.e., recognized sections) follows Miadlikowska \& Lutzoni (2000). Numbers associated with internodes represent ML bootstrap support values (based on 1000 pseudoreplicates). The ML tree for sections Retifoveatae and Peltigera (based on five loci: ITS, $\beta$-tubulin, COR1b, COR3, COR16; panel B) is adapted from Figure 1 of Magain et al. (2018). Clades were collapsed using FigTree v1.4.3 (Rambaut 2012). Clades containing more than two species are indicated as groups. The scales represent nucleotide substitutions per site.

\section{Materials and methods}

Specimens were examined under a Leica MZ6 dissecting microscope. A total of 20 ascospores from three apothecia were measured using a Leica DMLB compound microscope. For the descriptions and use of terminology we followed Vitikainen (1994: 5-17). Thin layer chromatography (TLC) was performed on four specimens, using solvents A, B' and C (Culberson \& Ammann 1979; Culberson \& Johnson 1982; solvent $\mathrm{C}$ is the same as solvent 'TA' of Holtan-Hartwig 1993). GenBank accession numbers for sequences from specimens P2039, P2062 and P1534 are provided in Magain et al. (2018), whereas the accession numbers for the remaining specimens are part of the voucher information provided below.

To determine the potential distribution of $P$. hydrophila, we used ecological niche modelling (ENM) techniques for the estimation of the habitat suitability for this species. The ENM was conducted using the maximum entropy method implemented in MaxEnt version 3.4.1 (Phillips et al. 2017, 2020) based on all known localities for $P$. hydrophila and all nineteen bioclimatic variables available in Worldclim 2.1 at 30 arc seconds (Phillips
\& Dudik 2008; Fick \& Hijmans 2017). We chose to use MaxEnt because it has been shown to work well for modeling species with very few known records (Elith et al. 2006; Pearson et al. 2006; de Siqueira et al. 2009). Locality data were thinned with a $5 \mathrm{~km}$ radius rule to minimize spatial autocorrelation using the $\mathrm{R}$ package spThin (Aiello-Lammens et al. 2015), and background extent was limited by a point buffer of 15 degrees. Model tuning included a variety of models reconstructed with different feature classes [i.e., linear (L), linear - quadratic (LQ), linear - quadratic - hinge $(\mathrm{LQH})$, and hinge $(\mathrm{H})]$ and different regularization multipliers $(1,2,3$, and 4) implemented in dismo (Hijmans et al. 2017) and ENMeval packages (Muscarella et al. 2014). Preparation runs were performed using the package Wallace version 1.0.6.2 to optimize the run settings (Kass et al. 2018). The area under the ROC curve (AUC) for each model created was calculated to estimate the credibility of the analysis. AUC values were calculated automatically and the higher AUC was selected as a reliable indicator of performance (Phillips et al. 2009; Peterson et al. 2011). Raster files were prepared in $R$ (R Core Team 2020) and all maps were edited in QGIS version 3.12.0 (QGIS Development Team 2020). 


\section{Taxonomy}

Peltigera hydrophila W. R. Buck, Miadl. \& Magain, sp. nov.

(Figs 2-4)

MycoBank MB 834180

Diagnosis: Unique in its glabrous thallus upper surface, which becomes deep bluish-violet when wet; possessing somewhat phyllidiate and indented thallus margins; apothecia round, flat to convex, reddish-brown to dark brown. Occurring in very humid to aquatic habitats. Differs from other species in section Peltigera, including its sister species $P$. aubertii, by its unique ITS1 hypervariable region (ITS1-HR in Miadlikowska et al. 2003; positions 182-335 of the ITS1 alignment in Magain et al. 2018) (Fig. 5).

Type: Chile, Región de Magallanes y Antártica Chilena, Prov. Antártica Chilena, Parque Nacional Cabo de Hornos, Isla Hermite, ENE arm of Seno Courtenay, head of the fjord, $54^{\circ} 34^{\prime} 33^{\prime \prime} \mathrm{S}, 71^{\circ} 10^{\prime} 36^{\prime \prime} \mathrm{W}$, floodplain forest with Nothofagus betuloides, $N$. antarctica, Drimys winteri, shrubs, pools and liverwort carpet ('Enchanted Forest'), on small granitic stones in river, occasionally submerged, January 11,2013 , B. Shaw 17848 (DUKE 0401861 - holotype; NY - isotype; DNA extraction \#P2039; GB ITS: MH758218).

Description. Thallus very small (to $4 \mathrm{~cm}$ in diameter), irregular and often partitioned, thin and fragile or rigid and brittle, tightly appressed to mosses and other substrates; lobes narrow, usually about $5 \mathrm{~mm}$ or less wide, occasionally up to $1 \mathrm{~cm}$, often with laminal cracks, lobe margins lacerate and often phyllidiate, lobe tips crenulate and curled, indented. Upper surface glabrous, smooth and matte, sometimes bulged along veins; small laminal patches of pruina (white crystals of calcium oxalate) often
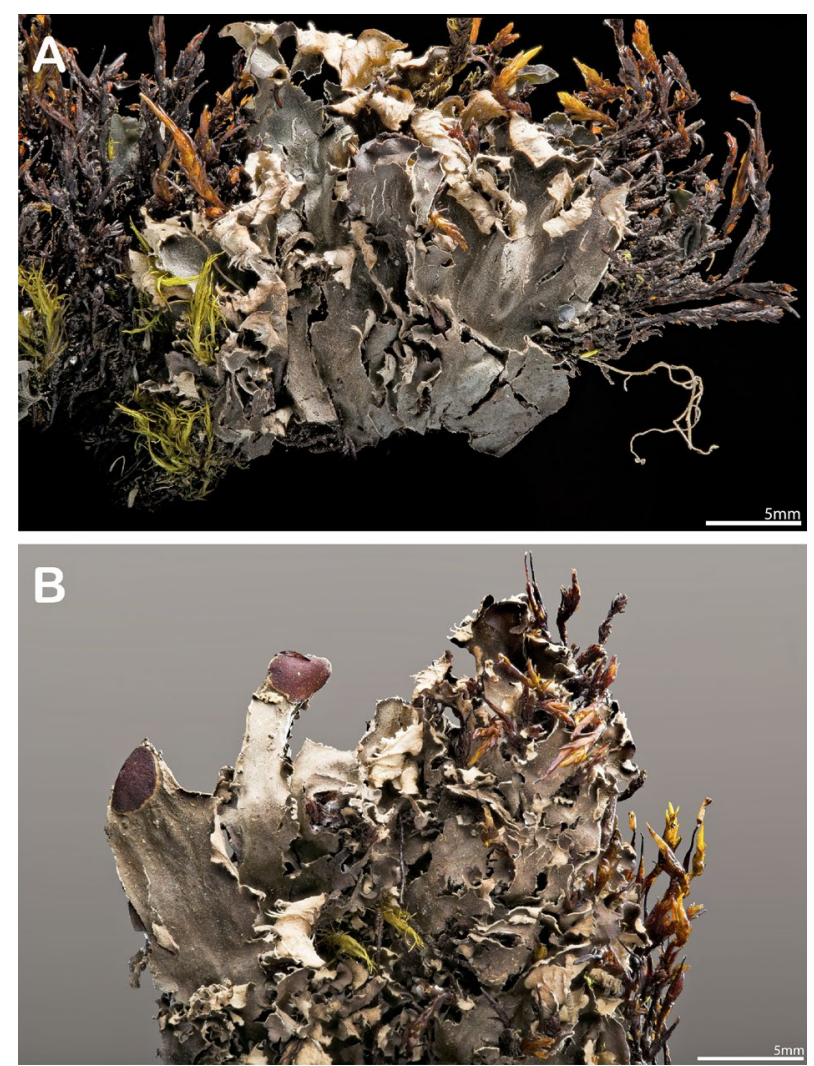

Figure 2. Peltigera hydrophila (N shore of Isla Hoste, Chile, W. R. Buck 62274). A - thallus habit; B - lobes with apothecia. Photo credit: T. Barlow.
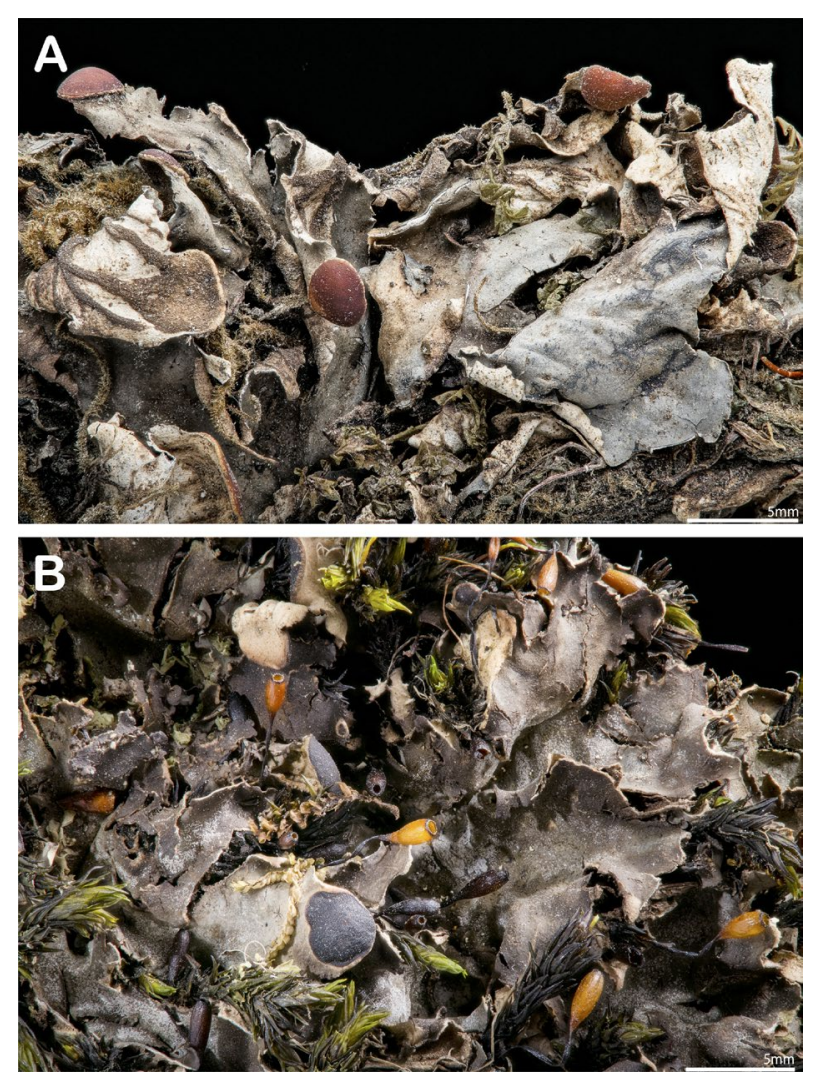

Figure 3. Peltigera hydrophila. A - thallus with apothecia (Reserva Nacional Mocho-Choshuenco, Chile, E. Terlova \& L. Lewis s.n.); B - lobes with patches of white pruina (crystals of calcium oxalate) and round apothecia from the aquatic specimen (E coast of Isla Hermite, Chile, W. R. Buck 62634). Photo credit: T. Barlow.

present, pale to dark gray with a bluish hint, or brownish and becoming dark and almost greenish-black in aquatic specimens when dry, deep bluish-violet when wet, often maculate. Lower surface smooth, compact, neither fluffy nor arachnoid, ochraceous or whitish toward the lobe tips and turning brown towards the thallus center. Veins smooth, compact, flat to slightly elevated and narrow and well defined in shape and color, to convex (ropy), usually pale (beige or ochre) toward lobe tips (sometimes brown from the tips especially under the fertile lobes), becoming brown and diffuse toward the thallus center, arranged in a parallel way along the lobes, weakly branched. Rhizines simple, smooth, composed of parallel conglutinated hyphae, not fluffy, often short, straight and pointed, to 1-2 mm long, arranged in short confluent rows along the veins, pale ochre toward the lobe tips and turning brown toward the center, or much longer and brown across the thallus. Apothecia always present, sometimes numerous, round or almost round, flat to convex, vertical to almost horizontal, reddish-brown to dark brown or black in some specimens, to $4 \mathrm{~mm}$ in diameter, developing on marginal parts of lobes, which are not always elongate, sometimes brown underneath. Ascospores Peltigera-type, mostly 3-septate, 37.5-55.0 × 3.5-6 $\mu \mathrm{m}$.

Photobiont. Nostoc phylogroup XXIII (shared with one specimen of $P$. aubertii from Chile; Magain et al. 2018; GB rbcLX: MH770527, MH770528, MH770529), which gives the thallus a deep bluish-violet color when wet. 

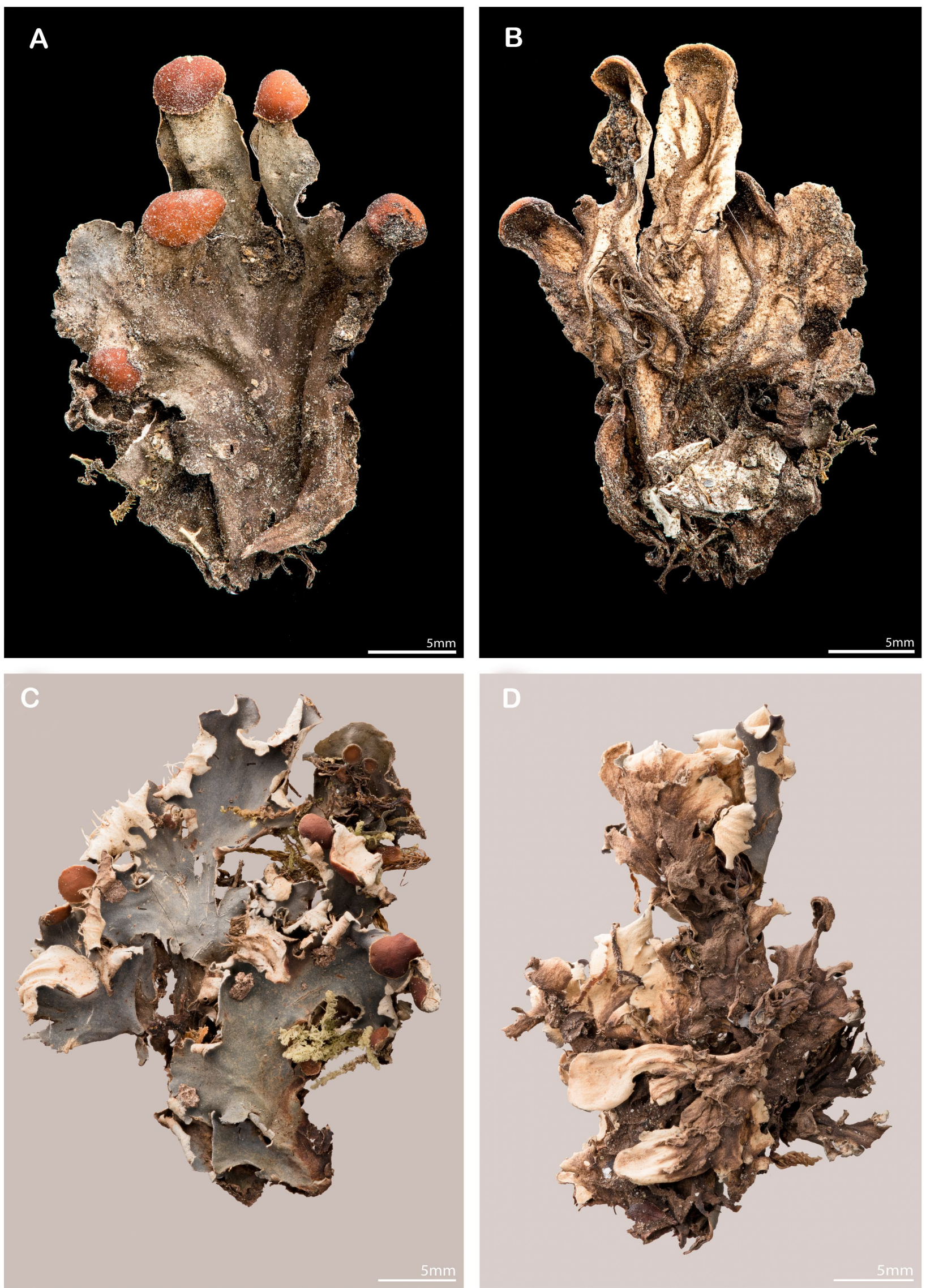

Figure 4. Peltigera hydrophila. A - fertile lobes (Reserva Nacional Mocho-Choshuenco, Chile, E. Terlova \& L. Lewis s.n.); B - under surface of the fertile lobes (Reserva Nacional Mocho-Choshuenco, Chile, E. Terlova \& L. Lewis s.n.); C - part of the thallus of the type specimen (Isla Hermite, Chile, B. Shaw 17848); D - under surface of the thallus of the type specimen (Isla Hermite, Chile, B. Shaw 17848). Photo credit: T. Barlow. 


\section{Clade 2a, section Peltigera}

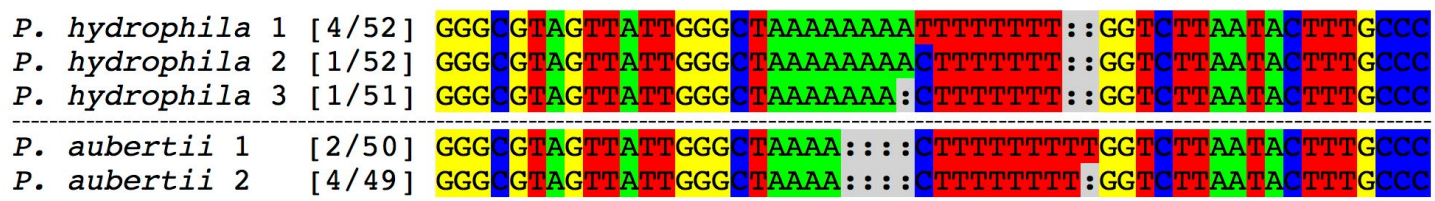

Figure 5. Sequences of the ITS1 hypervariable region (ITS1-HR; positions 182-335 of the ITS1 alignment; Clade 2a, Magain et al. 2018) from $P$. hydrophila and its sister species $P$. aubertii. In square brackets, the number of individuals represented by each sequence type is shown before the slash and the length of the sequence is provided after the slash.

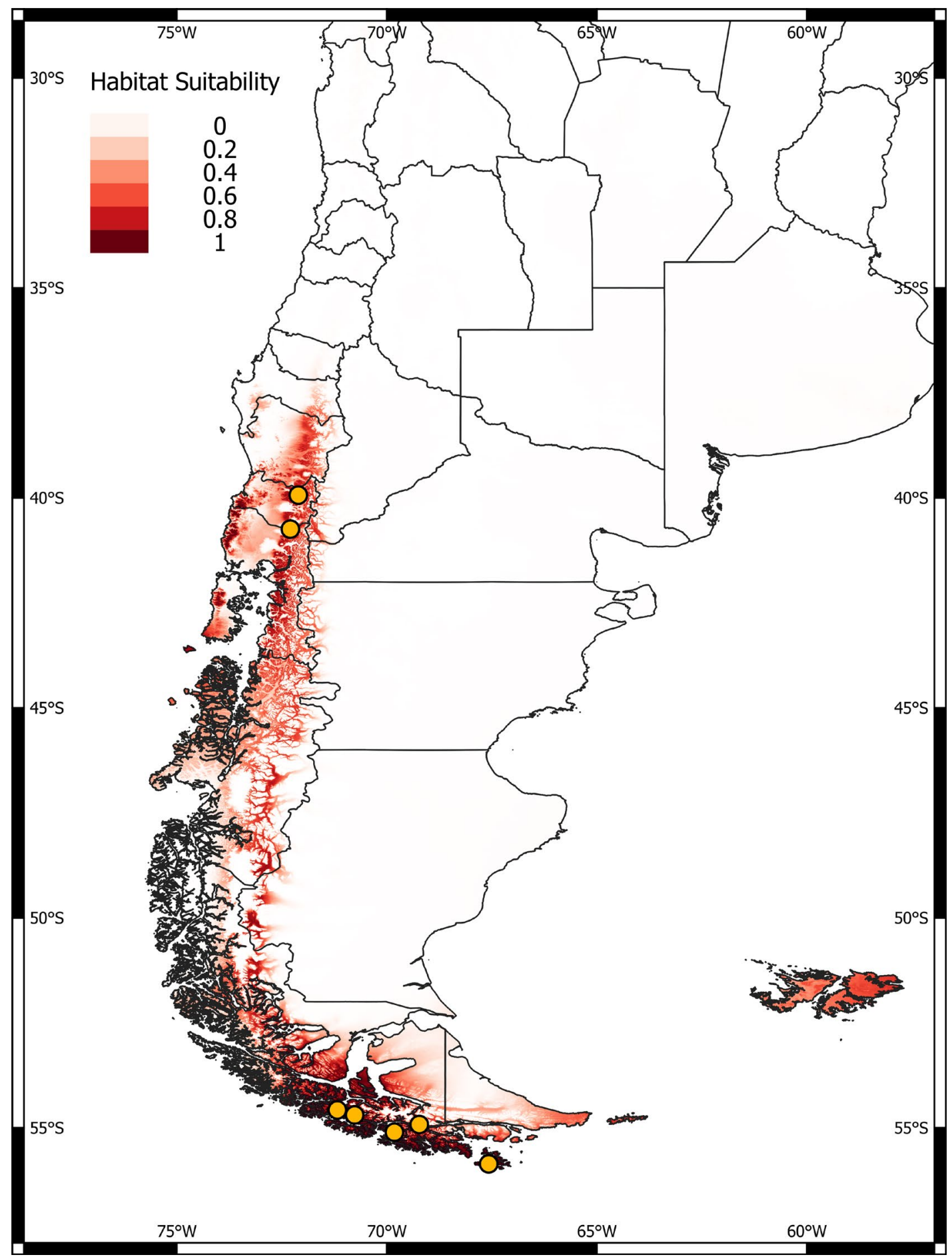

Figure 6. Currently known localities for Peltigera hydrophila (orange circles). A logistic projection (color gradient) shows the most suitable areas for the potential presence of this species. 

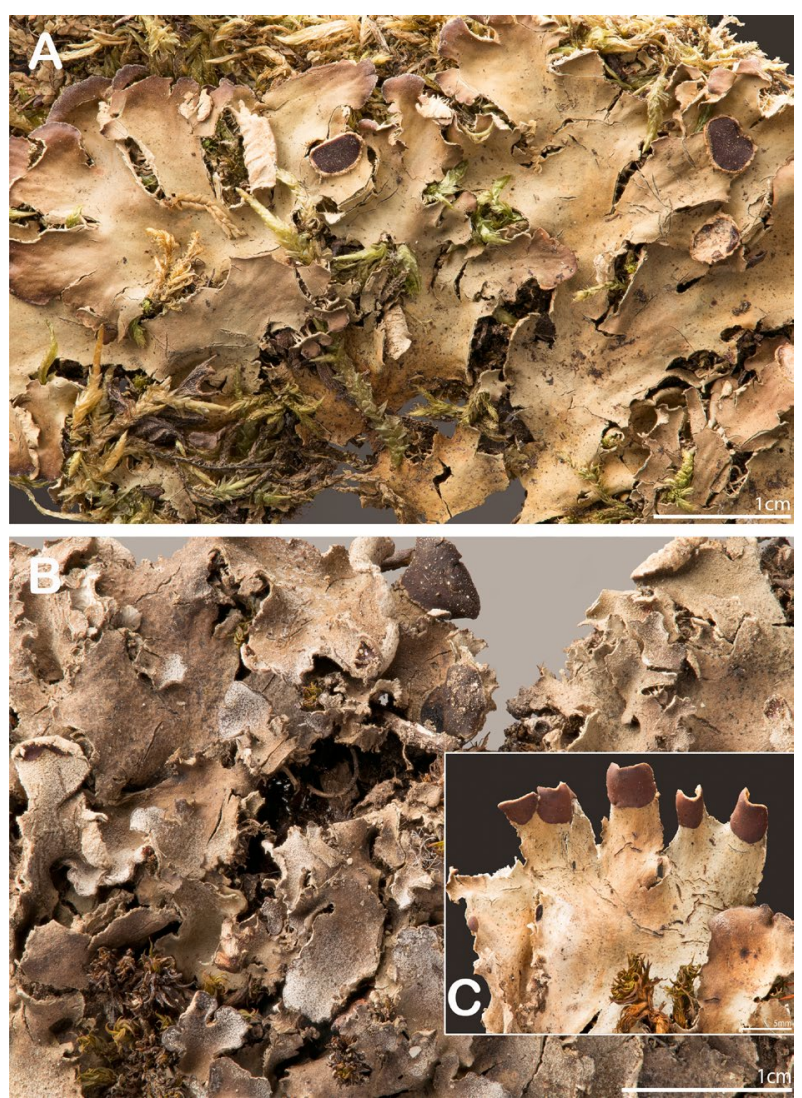

Figure 7. A - glabrous thallus with round, flat, 'horizontal' apothecia of $P$. frigida (Argentina, Tierra del Fuego, Isla Grande, S. Stenroos $2158, \mathrm{H}$ ); B - tomentous thallus of $P$. aubertii (Chile, Región de Magallanes y Antártica Chilena, Isla Navarino, B. Goffinet 10558, CONN); $\mathrm{C}$ - finger-shaped apothecia of $P$. aubertii (Región de Magallanes $\mathrm{y}$ Antártica Chilena, Isla Navarino, B. Goffinet 10559, CONN). Photo credit: T. Barlow.

Chemistry. No secondary metabolites were detected with TLC.

Etymology. The name acknowledges the water-loving nature of this species.

Ecology. On mossy rocks in semi-aquatic habitats (e.g., near waterfalls or along streams) or submerged, as well as on mosses and rocks in humid Nothofagus forests or shrubby and herbaceous vegetation in temperate areas of southern Chile.

Distribution. This species is currently known from seven collections in Chile, extending from Región de Los Ríos and Región de Los Lagos to the southernmost tip of Región de Magallanes within most of the range of the temperate rainforest (Fig. 6).

Notes. Because of its semi-aquatic habitat, P. hydrophila resembles in some features, e.g., the placement and shape (flat to convex) of the apothecia and the compact underside of the thallus and veins, the morphology of species from section Hydrothyriae, which are always submerged in streams in North America (Miadlikowska et al. 2014). Peltigera aubertii (type material from Kerguelen Island; Vitikainen 2002) and P. frigida (type material from Tierra del Fuego; Vitikainen 2002), two other species from section Peltigera that also can have reddish-brown, round, and flat, apothecia, are relatively common in Argentina and Chile (Vitikainen 2002; Martínez et al. 2003; Quilhot et al. 2012; Nelson \& Wheeler 2016), and are partially sympatric with $P$. hydrophila. However, the distribution of $P$. frigida does not extend north of Región de Los Ríos in Chile (Quilhot et al. 2012). The apothecia of P. aubertii and $P$. frigida (unlike $P$. hydrophila) are not convex, being mostly 'horizontal' in $P$. frigida (Fig. 7A), and vertical, finger-shaped, and often exceeding $4 \mathrm{~mm}$ in diameter in P. aubertii (Fig. 7C). Most importantly, the upper thallus surface of $P$. hydrophila is never tomentose like $P$. aubertii (Fig. 7B) nor glossy like P. frigida (Fig. 7A) (Vitikainen 2002). The ascospores are not discriminating among these three species - mostly 3-septate, similar in shape and size ( $P$. frigida: $40-44 \times 3.5-6.0 \mu \mathrm{m}$ according to Vitikainen 2002 ; $P$. aubertii: $37.5-50 \times 3.7-6.25 \mu \mathrm{m}$ from this study). The only specimen of $P$. aubertii that shares Nostoc phylogroup XXIII with $P$. hydrophila consists of a few fertile lobes in rather poor condition and did not yield the same bluish-violet color of the wet thallus as observed in $P$. hydrophila. Four of the collections of $P$. hydrophila were found on mossy rocks occasionally submerged or under running water (i.e., small waterfalls or streams), but the remaining three were growing in very moist but non-aquatic conditions.

The range of $P$. hydrophila extends along the temperate macroclimate of southern Chile, including the wet coast lines of the antiboreal macroclimate (Luebert $\&$ Pliscoff 2017). Due to the continuity of the temperate macroclimate along continental Chile in the Aisén region,
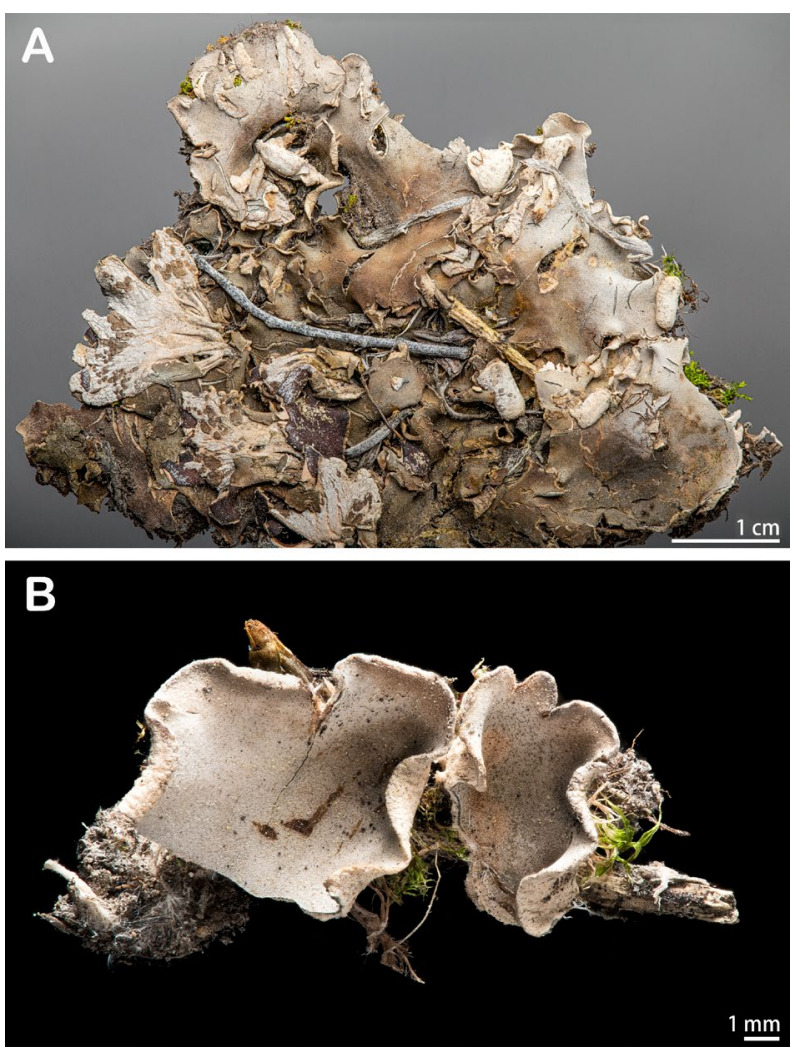

Figure 8. Peltigera 'xerica' $(P$. sp. 16; Oregon, USA, B. McCune 31966). A - thallus with visible patches of cortex on the underside of apothecia; B - densely tomentose lobe tips and thickened margins. Photo credit: T. Barlow. 


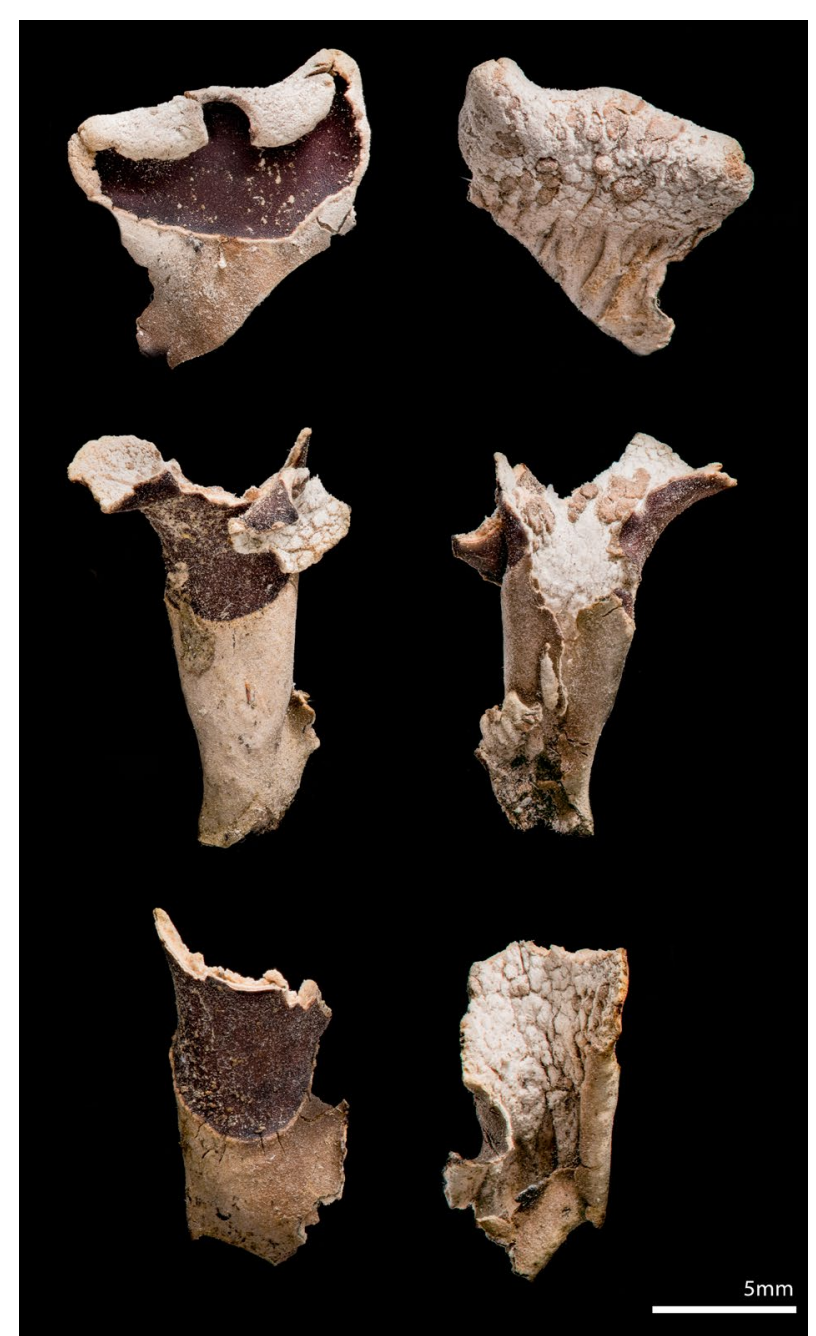

Figure 9. Apothecia of Peltigera 'xerica' ( $P$. sp. 16; Oregon, USA, B. McCune 31966). Photo credit: T. Barlow.

it is expected that the large gap in its current geographical distribution (Fig. 6) results from the lack of collections, but it is also possible that the species has been overlooked or misidentified in the past (Quilhot et al. 2012). All models for the current distribution of $P$. hydrophila had AUCs $>0.90$ after tuning. The chosen model complexity was LQH_1, with a resulting AUC value of 0.995. According to this result (Fig. 6), the area suitability for P. hydrophila (above 0.9 ) covers $16182.2 \mathrm{~km}^{2}$, whereas at its minimum training presence (understood as the lowest predicted suitability value for a known occurrence point), it covers a total of $36840.7 \mathrm{~km}^{2}$. The predicted distribution ranges from Región del Biobío to Región de Magallanes in Chile, with a few extensions across the Andes to Argentina, in the low valleys that allows the entrance of the Valdivian rain forest to the eastern slopes of the Andes Cordillera. In Región de Aisén the model suggests that $P$. hydrophila could be present in highly oceanic areas with high precipitation in the temperate hyperoceanic macroclimate (Luebert \& Pliscoff 2017), with another high probability of occurrence in the boreal hyperoceanic macroclimate following the outermost islands of southern Chile and Argentina, including Tierra del Fuego and Staten Island (Isla de los Estados). Additionally, our model suggests that $P$. hydrophila could be present in the Falkland Islands
(Islas Malvinas; Fig. 6), where a recent checklist (Fryday et al. 2019) indicates the presence of four Peltigera species, one of them being $P$. aubertii. This distribution is not uncommon among temperate South American endemics (e.g., Pseudocyphellaria vaccina (=Podostictina endochrysa) and Polychidium polychidioides).

Another species representing one of the earliest divergences within section Peltigera, $P$. sp. 16 ( $P$. 'xerica') sister to a clade consisting of $P$. frigida and $P$. patagonica - is the only representative from North America in clade 2b (USA, NE Oregon, Hart Mountain National Antelope Refuge, $\mathrm{N}$ of Hotsprings campground, $42^{\circ} 30^{\prime} 10^{\prime \prime} \mathrm{N}$, $110^{\circ} 41^{\prime} 25^{\prime \prime} \mathrm{W}$, alt. $1822 \mathrm{~m}$, on soil among rhyolite outcrops in Artemisia steppe, June 2012, B. McCune 31966, McCune pers. herb., DNA extraction \#P2186) (Fig. 1B; see also Magain et al. 2018). Morphologically, this putative species resembles the tomentose morphotype of $P$. ponojensis, but develops patches of cortex on fertile lobes under the relatively large apothecia, which become lacerated (Figs 8 and 9). The only specimen known of this taxon was collected from a very dry, high desert habitat.

Peltigera sp. 13 (P. 'inopinata'), from China, is the second species known in section Retifoveatae (Fig. 1B) (Yunnan Province, Lijiang Prefecture, Lijiang Co. S of Lijiang, Jihue village, Laojunshan Mountain, at the border with Jianchuan Co., montane forest dominated by Abies and further up by Rhododendron, along trail from parking lot to the peak, at the base of tree, $26^{\circ} 39^{\prime} 13^{\prime \prime} \mathrm{N}$, 99 $46^{\prime} 35^{\prime \prime} \mathrm{E}$, alt. $3451 \mathrm{~m}$, July 16, 2010, B. Goffinet 9974
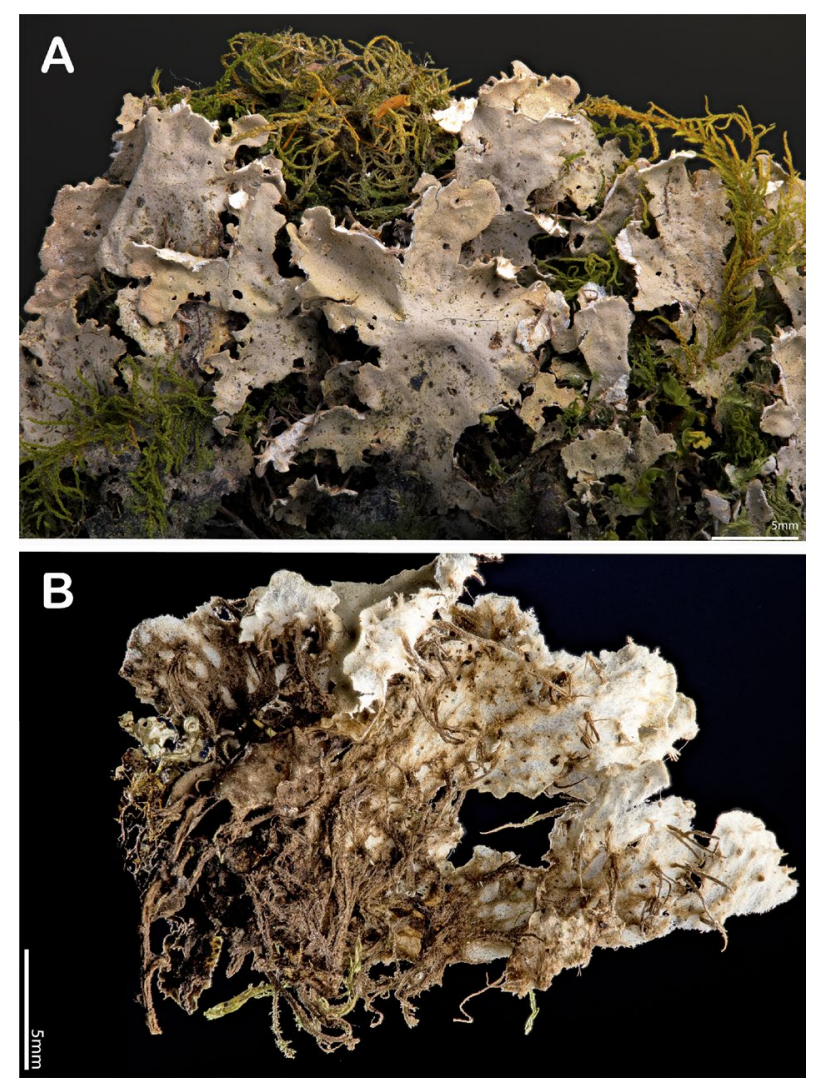

Figure 10. Peltigera 'inopinata' ( $P$. sp. 13; China, Yunnan Province, B. Goffinet 9974). A - thallus growing on mosses; B - under surface of the thallus. Photo credit: T. Barlow. 
with L. Wang, S. L. Guo \& S. Y. Huang s.n. (CONN), DNA extraction \#P2225). Unlike its sister species $P$. retifoveata, it does not produce secondary compounds detectable by TLC and has a small, pitted, crenulate thallus with non-squarrosely branched rhizines (Fig. 10). For both $P$. 'xerica' and $P$. 'inopinata', we are awaiting further collections before formally describing them.

Specimens examined. CHILE. Región de Magallanes y Antártica Chilena, Antártica Chilena Province, Comuna Cabo de Hornos, Parque Nacional Alberto de Agostini, N shore of Isla Hoste, Caleta Coloane, $55^{\circ} 06^{\prime} 22^{\prime \prime} \mathrm{S}, 69^{\circ} 49^{\prime} 06^{\prime \prime} \mathrm{W}$, bryophyte-dominated rocky area in front of glacier, on wet horizontal rock among bryophytes, January 11, 2014, W. R. Buck 62274 (NY), DNA extraction \#P6153 (GB ITS: MN886243); Comuna Cabo de Hornos, Parque Nacional Alberto de Agostini, E coast of Isla

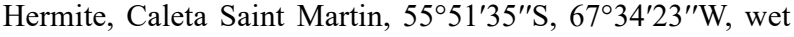
Nothofagus antarctica-Drimys forest beside small stream with carpet of hepatics and Hymenophyllaceae on forest floor, on rock among mosses in stream, January 19, 2014, W. R. Buck 62634 (NY), DNA extraction \#P6152 (GB ITS: MN886242); Comuna Cabo de Hornos, Parque Nacional Alberto de Agostini, Isla Grande de la Tierra del Fuego, immediately W of Glaciar Italia along the $\mathrm{N}$ side of the Brazo Noroeste of the Beagle Channel, 54 $55^{\prime} 21^{\prime \prime} \mathrm{S}, 69^{\circ} 13^{\prime} 34^{\prime \prime} \mathrm{W}$, shrubby and herbaceous vegetation along small waterfall on steep E-facing slope and adjacent granitic dome, submerged in small waterfall, January 19, 2005. W. R. Buck 47968 (NY), AFTOL-1838, DNA extraction \#P1534; Comuna Cabo de Hornos, Parque Nacional Alberto de Agostini, Isla Grande de la Tierra del Fuego, E end of Seno Puga, SE corner just E of large waterfall, 54 $41^{\circ} 43^{\prime \prime} \mathrm{S}$, $70^{\circ} 45^{\prime} 52^{\prime \prime} \mathrm{W}$, wet Nothofagus betuloides forest and adjacent Magellanic tundra, on coastal soil, January 9, 2014, W. R. Buck 62144 (NY). Región de Los Lagos, Parque Nacional Puyehue, from Park Headquarters to trail junction to Bertin Lake through patchwork of shrublands transitioning to old coigue, $40^{\circ} 44^{\prime} 38^{\prime \prime} \mathrm{S}$, $72^{\circ} 17^{\prime} 45^{\prime \prime} \mathrm{W}$, alt. $1450 \mathrm{ft}$, on mineral soil, January 23, 2008, T. Wheeler \& P. Nelson 5191 (CONC), DNA extraction \#P2062. Región de Los Ríos, Reserva Nacional Mocho-Choshuenco, $39^{\circ} 56^{\prime} 2^{\prime \prime} \mathrm{S}, 72^{\circ} 6^{\prime} 21^{\prime \prime} \mathrm{W}$, alt. $1172 \mathrm{~m}$, primary Valdivian temperate Nothofagus forest, on mossy vertical boulder behind a small waterfall, March 14, 2017, E. Terlova \& L. Lewis s.n., ChileMocho-1-C1-P1-NM-67, DUKE 0402892, DNA extraction \#P6197 (GB ITS: MN886244).

\section{Acknowledgements}

We are very thankful to: 1) our collaborators: B. Shaw, T. Wheeler, P. Nelson, B. McCune and B. Goffinet for providing collections for the new Peltigera species; 2) the GoLife team for field assistance in Chile, especially E. Terlova and L. Lewis for collecting one of the specimens of $P$. hydrophila; and 3) the reviewers, D. Ertz and B. Goffinet for their comments, which greatly improved the manuscript. This work was financially supported by NSF GoLife DEB-1541548 to FL and JM.

\section{References}

Aiello-Lammens, M. E., Boria, R. A., Radosavljevic, A., Vilela, B. \& Anderson, R. P. 2015. spThin: an R package for spatial thinning of species occurrence records for use in ecological niche models. Ecography 38: 541-545.

Chagnon, P. L., Magain, N., Miadlikowska, J. \& Lutzoni, F. 2019. Species diversification and phylogenetically constrained symbiont switching generated high modularity in the lichen genus Peltigera. Journal of Ecology 107: 1645-1661.
Culberson, C. F. \& Ammann, K. 1979. Standardmethode zur Dünnschichtchromatographie von Flechtensubstanzen. Herzogia 5: 1-24.

Culberson, C. F. \& Johnson, A. 1982. Substitution of methyl tert-butyl ether for diethyl ether in the standardized thin-layer chromatographic method for lichen products. Journal of Chromatography 128: 253-259.

De Siqueira, M. F., Durigan, G., de Marco Júnior, P. \& Peterson, A. T. 2009. Something from nothing: Using landscape similarity and ecological niche modeling to find rare plant species. Journal for Nature Conservation 17: 25-32.

Elith, J., Graham, C. H., Anderson, R. P., Dudík, M. Ferrier, S., Guisan, A., Hijmans, R. J., Huettmann, F., Leathwick, J. R., Lehmann, A., Li, J., Lohmann, L. G., Loiselle, B. A., Manion, G., Moritz, C., Nakamura, M., Nakazawa, Y., Overton, J. M. M., Peterson, A. T., Phillips, S. J., Richardson, K., Scachetti-Pereira, R., Schapire, R. E., Soberón, J., Wiliams, S., Wisz, M. S. \& Zimmermann, N. E. 2006. Novel methods improve prediction of species' distributions from occurrence data. Ecography 29: 129-151.

Fick, S. E. \& Hijmans, R. J. 2017. WorldClim 2: new 1 km spatial resolution climate surfaces for global land areas. International Journal of Climatology 37: 4302-4315.

Fryday, A. M., Orange, A., Ahti, T., Øvstedal, D. O. \& Crabtree, D. E. 2019. An annotated checklist of lichen-forming and lichenicolous fungi reported from the Falkland Islands (Islas Malvinas). Glalia 8: $1-100$.

Hijmans, R. J., Phillips, S., Leathwick, J. \& Elith, J. 2017. dismo: Species distribution modeling. R package version 1.1-4. Retrieved from http:// cran.r-project.org/package=dismo

Holtan-Hartwig, J. 1993. The lichen genus Peltigera, exclusive of the P. canina group, in Norway. Sommerfeltia 15: 1-77.

Kass, J. M., Vilela, B., Aiello-Lammens, M. E., Muscarella, R., Merow, C. \& Anderson, R. P. 2018. Wallace: A flexible platform for reproducible modeling of species niches and distributions built for community expansion. Methods in Ecology and Evolution 9: 1151-1156.

Luebert, F. \& Pliscoff, P. 2017. Sinopsis bioclimática y vegetacional de Chile. Editorial Universitaria, Santiago de Chile, Chile.

Magain, N., Miadlikowska, J., Goffinet, B., Sérusiaux, E. \& Lutzoni. F. 2017a. Macroevolution of specificity in cyanolichens of the genus Peltigera section Polydactylon (Lecanoromycetes, Ascomycota). Systematic Biology 66: 74-99.

Magain, N., Miadlikowska, J., Mueller, O., Gajdeczka, M., Salamov, A., Grigoriev, I., Goffinet, B., Sérusiaux, E. \& Lutzoni, F. 2017b. Conserved genomic collinearity as a source of broadly applicable, fast evolving, markers to resolve species complexes: a case study using the lichen-forming genus Peltigera section Polydactylon. Molecular Phylogenetics and Evolution 117: 10-29.

Magain, N., Truong, C., Goward, T., Niu, D., Goffinet, B., Sérusiaux, E., Vitikainen, O., Lutzoni, F. \& Miadlikowska, J. 2018. Global species delimitation of Peltigera section Peltigera (lichenized Ascomycota, Lecanoromycetes) reveals high species richness with complex biogeographical history and patterns of associations. Taxon 67: $836-870$.

Martínez, I., Burgaz, A. R., Vitikainen, O. \& Escudero, A. 2003. Distribution patterns in the genus Peltigera Willd. Lichenologist 35: 301-323.

Miadlikowska, J. \& Lutzoni, F. 2000. Phylogenetic revision of the genus Peltigera (lichen-forming ascomycetes) based on morphological, chemical and large subunit nuclear ribosomal DNA data. International Journal of Plant Sciences 161: 925-958.

Miadlikowska, J., Lutzoni, F., Goward, T., Zoller, S. \& Posada, D. 2003. New approach to an old problem: Incorporating signal from gap-rich regions of ITS and nrDNA large subunit into phylogenetic analyses to resolve the Peltigera canina species complex. Mycologia 95: $1181-1203$.

Miadlikowska, J., Kauff, F., Högnabba, F., Oliver, J. C., Molnár, K., Fraker, E., Gaya, E., Hafellner, J., Hofstetter, V., Gueidan, C., 
Kukwa, M., Lucking, M., Björk, C., Sipman, H. J. M., Burgaz, A. R., Thell, A., Passo, A., Myllys, L., Goward, T., Fernández-Brime, S., Hestmark, G., Lendemer, J., Lumbsch, H. T., Schmull, M., Schoch, C., Sérusiaux, E., Maddison, D. R., Arnold, A. E., Stenroos, S. \& Lutzoni, F. 2014. Multigene phylogenetic synthesis for the class Lecanoromycetes (Ascomycota): 1307 fungi representing 1139 infrageneric taxa, 312 genera and 66 families. Molecular Phylogenetics and Evolution 79: 132-168.

Miadlikowska, J., Richardson, D., Magain, N., Ball, B., Anderson, F., Cameron, R., Lendemer, J., Truong, C. \& Lutzoni, F. 2014. Phylogenetic placement, species delimitation, and cyanobiont identity of endangered aquatic Peltigera species (lichen-forming Ascomycota, Lecanoromycetes). American Journal of Botany 101: 1141-1156.

Miadlikowska, J., Magain, N., Pardo-De la Hoz, C., Niu, D., Goward, T., Sérusiaux, E. \& Lutzoni, F. 2018. Species in section Peltidea (aphthosa group) of the genus Peltigera remain cryptic after molecular phylogenetic revision. Plant and Fungal Systematics 63: 45-64.

Muscarella, R., Galante, P. J., Soley-Guardia, M., Boria, R. A., Kass, J. M., Uriarte, M. \& Anderson, R. P. 2014. ENMeval: An R package for conducting spatially independent evaluations and estimating optimal model complexity for Maxent ecological niche models. Methods in Ecology and Evolution 5: 1198-1205.

Nelson, P. R. \& Wheeler, T. B. 2016. Persistence of epiphytic lichens along a tephra-depth gradient produced by the 2011Puyehue-Cordón Caulle eruption in Parque Nacional Puyehue, Chile. Bosque 37: 97-105.

Pardo-De la Hoz, C. J., Magain, N., Goward, T. Lutzoni, F., Restrepo, S. \& Miadlikowska, J. 2018. Contrasting symbiotic patterns in two sister lineages of trimembered lichens in the genus Peltigera. Frontiers in Microbiology 9: 2770.

Pearson, R. G., Raxworthy, C. J, Nakamura, M. \& Peterson, A. T. 2006. Predicting species distributions from small numbers of occurrence records: a test case using cryptic geckos in Madagascar. Journal of Biogeography 34: 102-117.

Peterson, A. T., Soberón, J., Pearson, R. G., Anderson, R. P., Martinez-Meyer, E., Nakamura, M. \& Araújo, M. B. 2011. Evaluating Model Performance and Significance. In: Ecological Niches and Geographic Distributions. Princeton, New Jersey: Monographs in Population Biology, 49. Princeton University Press.

Phillips, S. J. \& Dudik, M. 2008. Modeling of species distributions with Maxent: new extensions and a comprehensive evaluation. Ecography 31: 161-175.

Phillips, S. J., Dudík, M. \& Schapire, R. E. 2020. Maxent software for modeling species niches and distributions (Version 3.4.1). Available from url: http://biodiversityinformatics.amnh.org/open_source/ maxent/. Accessed on 2020-3-26.

Phillips, S. J., Anderson, R. P., Dudík, M., Schapire, R. E. \& Blair, M. E. 2017. Opening the black box: an open-source release of Maxent. Ecography 40: 887-893.

Phillips, S. J., Dudík, M., Elith, J., Graham, C. H., Lehmann, A., Leathwick, J. \& Ferrier, S. 2009. Sample selection bias and presence-only distribution models: implications for background and pseudo-absence data. Ecological Applications 19: 181-197.

Quilhot, W., Cuellar, M., Diaz, R., Riquelme, F. \& Rubio, C. 2012. Lichens of Aisen, Southern Chile. Gayana Botanica 69: 57-87.

Rambaut, A. 2012. FigTree v.1.4.3. Computer program distributed by the author, website: http://tree.bio.ed.ac.uk/software/figtree

Vitikainen, O. 1994. Taxonomic revision of Peltigera (lichenized Ascomycotina) in Europe. Acta Botanica Fennica 152: 1-96.

Vitikainen, O. 2002. Notes on Peltigera (Peltigeraceae) in southern South America and Antarctic region. Mitteilungen aus dem Insitut für Allgemeine Botanik in Hamburg 30-32: 297-303. 